\title{
Review
}

\section{Creativity and Legitimacy in Constitutional Law}

\author{
Vince Blasi
}

Structure and Relationship in Constitutional Law. By Charles L. Black, Jr. Baton Rouge: Louisiana State University Press, 1969. Pp. ix, 98. $\$ 3.95$.

Professor Charles Black's Structure and Relationship in Constitutional Law deserves more attention than it has apparently received. ${ }^{1}$ First delivered as the Edward Douglass White lectures at Louisiana State University in 1968, the book presents a graceful, courteous, yet strongly-committed discussion of a largely neglected method of reasoning in constitutional law: what Black calls "the method of inference from the structures and relationships created by the constitution in all its parts or in some principal part," as contrasted with the dominant method of "purported explication or exegesis of the particular textual passage considered as a directive of action ... ."2 In presenting the argument for this method of structural inference, Black carefully states that he is not referring to "the higher speculations of jurisprudence; I am interested, rather, in the thing that would probably most interest an anthropologist: What basic kinds of legal reasoning, broadly, does the ordinary, competent American judge see as being open to him when he has to ascertain and fix the right law for application to a case before him?'3 This relatively modest question carries within itself, however, most of the "higher speculations" about judicial consciousness and decisional legitimacy which have wracked the field of constitutional theory in the last two decades, and it is a tribute to Professor Black's skill that he is able, within his limited framework, to make some suggestive contributions.

† Associate Professor of Law, University of Michigan. B.A. 1964, Northwestern University; J.D. 1967, University of Chicago.

1. It has been the subject of the following reviews: G. Casper, 37 U. CHr. L. REv. 196 (1969); A. Saipa, 21 Hast7ngs L.J. 235 (1969); C. Rice, 38 Fordiam I. REv. 603 (1970); and D. Gould, 22 AD. L. REv. 493 (1970).

2. C. BLAcK, Structure AND ReLationship In Constitutionat, Law 7 (1969) [hereinafter cited to page number only]. For a recent elaboration of the structural method, see Black, The Unfinished Business of the Warren Court, 46 WASH. L. REV. 3 (1970).

3. P. 4 . 
I.

Professor Black introduces his theme of structural inference with a discussion of Carrington $v$. Rash, ${ }^{4}$ in which the Court struck down, on equal protection grounds, a Texas constitutional provision that denied U.S. military personnel eligibility to vote in the county in which they were stationed unless they had been residents of that county at the time of entering the service. Because the Court chose the equal protection rubric, says Black, "the inquiry had to be whether the particular limitation imposed was 'reasonable." "' Since Texas put forward several plausible reasons for denying servicemen the vote-they are subject to special pressures, they might be present in such numbers as to overwhelm a small community, many will be transients, their residence in the area is involuntary-Black finds it impossible to characterize the Texas law as "wholly capricious and arbitrary." ${ }^{\circ}$ Yet he is prepared to strike down the law on the basis of his alternative methodology: "The ground I would have preferred is one sounding in the structure of federal union, and in the relation of federal to state governments; it can point to no particular text as its authority. This is a mode of reasoning which tends to be rejected, or ignored as a possibility, by our legal culture." In the case of the Texas voting disqualification, his structural methodology would have enabled Black to embrace an absolute rule - "no state may annex any disadvantage simply and solely to the performance of a federal duty"8_-rather than the "reasonableness" standard which he finds necessitated by reliance on the Equal Protection Clause.

Similarly, Professor Black is not entirely happy with the "textual exegesis" by which the First Amendment's prohibition of congressional abridgment of free speech restricts the states through the prism of the Due Process Clause of the Fourteenth Amendment. He notes that in the very case in which the Court first articulated a principle of free speech applicable to the states, Gitlow v. New York, ${ }^{9}$ the majority affirmed the defendant's conviction for publishing a rather abstract polemical essay. He traces this result in part to the Court's application of "the same rule to state laws infringing the freedom of speech that held good for state

\footnotetext{
4. 380 U.S. 89 (1965).

5. P. 10.

6. Id.

7. P. 11

8. Id.

9. 268 U.S. 652 (1925).
} 
laws in general-they must not be 'arbitrary.' "10 Moreover, he asserts, the arbitrariness concept "has continued to exert a sort of influence" as evidenced by the Court's citation of Gitlow in its opinion in Dennis $v$. United States ${ }^{11}$ even though the Dennis case involved a federal law clearly subject to the First Amendment.

"These confusions," suggests Black, "lead the mind to search for a more adequate basis for federal constitutional protection against state interferences with the freedom of speech."12 It is his thesis "that such a basis exists-that the nature of the federal government, and of the states' relations to it, compels the inference of some federal constitutional protection for free speech, and gives to a wide protection an inferential support quite as strong as the textual support we have been examining."13 Because the structure of our federal government is that of representative democracy, he notes, "discussion of all questions which are in the broadest sense relevant to Congress's work is, quite strictly, a part of the working of the national government. If it is not, what is our mechanism for accommodating national political action to the needs and desires of the people? And if it is, does it not reasonably follow that a state may not interfere with it?" 14

To supplement the inferences that might be said to flow from the mere existence of a federal government, and from the important role in the overall system assigned to the electorate, Black finds another wellspring in the Constitution's passing recognition, without exhaustive refinement into attendant rights and duties, of the concept of citizenship. He would infer from the mention of citizenship in the Fourteenth Amendment a broad congressional "power to declare and give effect to the rights of citizenship as positive rights to full membership in the community, without segregation and isolation,"15 and thus he finds altogether unnecessary (though not untenable) the Supreme Court's reliance on the Commerce Clause to uphold the public accommodations section of the 1964 Civil Rights Act, ${ }^{16}$ as well as, presumably, ${ }^{17}$ the Court's invocation of the Thirteenth Amendment to sustain federal open housing legislation. Similarly, freedom from religious coercion

10. P. 37.

11. 341 U.S. 494 (1951).

12. P. 39 .

13. $I d$.

14. P. 43

15. P. 58.

16. Heart of Atlanta Motel v. United States, 379 U.S. 241 (1964); Katzenbach v. McClung, 379 U.S. 294 (1964).

17. Jones v. Mayer, 392 U.S. 409 (1968), had not yet come down when Black delivered the lectures. 
(though not necessarily from establishment), he believes, is a right properly inferable from the status of citizenship without need to resort to the incorporation process with its dubious historical underpinnings and its aftertaste of due process-arbitrariness thinking. ${ }^{18}$ Likewise, "an inference of immunity from arbitrary arrest, oppressive interrogation, unfair trial, and the like might easily have been drawn from the status of citizenship, once the decision had been taken to look on that status as more than the right to a label."10

Lest it be thought, however, that his approach is a radical departure in legal reasoning - or, by the same token, totally bereft of support in precedent-Black points out that inferences from structure and relationship have long been a part of the American system of constitutional adjudication. Marshall's reasoning, for example, in the second half of McCulloch v. Maryland, ${ }^{20}$ rejecting the state's asserted power to tax a federal instrumentality, "is, as I read it, essentially structural. It has to do in great part with what he conceives to be the warranted relational proprieties between the national government and the government of the states, with the structural corollaries of national supremacy-and, at one point, of the mode of formation of the Union." 21 The 1868 case of Crandall $v$. Nevada, ${ }^{22}$ invalidating a state head tax on the exit of persons from its borders, is "of the highest methodological interest" since it was based on neither the Exports-Imports Clause nor the Commerce Clause, but rather on "a theory of membership in the national polity which includes the right to travel unimpeded from state to state." ${ }^{23}$ Black also detects structural reasoning in the many cases testing state economic regulations against the negative implications of the Commerce Clause. ${ }^{24} \mathrm{He}$ admits that "variant theories" have appeared in the cases, but he is willing to "assert summarily that what sense the subject has finally received-and that is not total sense-has come precisely from its transmutation from a problem in textual construction and single-text implication into a problem about the economic structure of

18. Pp. 61-63.

19. P. 63. Nor are aliens left out of the scheme of inferences. Since aliens "stay here by national permission, on such terms as the nation imposes," "are to be naturalized when and as Congress prescribes," and since "[o]ur relations with them vitally concern our foreign relations and our foreign commerce," Black finds proper "a general doctrine of national constitutional preemption when it comes to most state discriminations against them." Pp. 64-65.

20. 17 U.S. (4 Wheat.) 316 (1819).

21. P. 15 .

22. 73 U.S. (6 Wall.) 35 (1868).

23. Pp. 15-16.

24. For a collection of such cases see, e.g., Lockhart, Ramisar \& Choper, ConstrivTIONAL LAW ch. 6 (3rd ed. 1970). 
nationhood-about the implications of the fact that we are one people, commercially as otherwise." ${ }_{25}$ Black is thus protesting not the exclusivity of the textual mode so much as the "stylistic preference" by which judges-especially twentieth-century judges-have come to employ the reasoning process of textual interpretation over that of structural and relational inference.

The last of his three lectures is devoted to an interesting variant of the main theme: not only may specific rights and duties be inferred from the structures and relationships set up by the Constitution, but general approaches to exercising the function of judicial review may be similarly inferred. Thus, justices should not always be racked by self-doubt and intimations of illegitimacy, or be deferential to the judgments of others when they "confront," in Black's language, officials and institutions in the forum of constitutional review. Deference is due only sometimes, depending on "[w] ho, before the Court acts, has made the critical determination which the Court is asked to reverse?"20

To begin with, insofar as "legitimacy in origin is relevant to judicial or public attitude toward the judicial work"-a question on which Black takes no stand- "the Court ought to feel no slightest embarrassment about its work of reviewing state acts for their federal constitutionality."27 Marshall's effort in Marbury v. Madison ${ }^{28}$ to justify judicial review of acts of Congress "may be thought to pose a problem-a problem to which the right solution was found, I think, but a problem nonetheless." 29 But "[t]here simply is no problem about the fundamental legitimacy of judicial review of the actions of the states for federal constitutionality. Article VI says as much, literally and directly.... On the whole, there is nothing in our entire governmental structure which has a more leak-proof claim to legitimacy than the function of the courts in reviewing state acts for federal constitutionality." 30 Indeed, Black's method of structural and relational inferences leads him to suggest that "Congress could have provided for this even without an Article III, simply by creating a court and endowing it with the power to perform this necessary and proper function." 31

Moreover, even when actions of the federal government are under constitutional scrutiny so that the Court's warrant must flow from Mar-

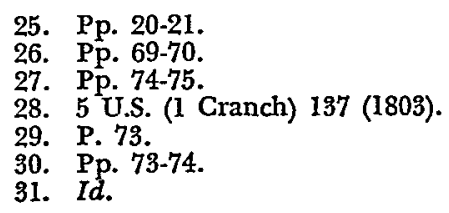


bury, judicial self-doubt is inappropriate when "what is actually involved is a confrontation between the Court and some official to whose judgment on constitutionality none of the piously repeated rules of deference and restraint have anything like the application they might be thought to have to Congress." 32 In particular, police practices, even those of federal officials, are not entitled to the same presumption of constitutionality that should be accorded acts of Congress, otherwise the defendant "never gets a responsible and competent judgment on the constitutionality of what has been done to him, never gets a judgment from anybody except his formal adversaries in the criminal process. That cannot be right." 33

Likewise, actions instituted by administrative officials under broad legislative delegations of authority-Black mentions as examples the Secretary of State's passport decision at issue in Kent v. Dulles ${ }^{34}$ and the World War II internment of Japanese-American citizens which was ordered, at least formally, by the military commander for California ${ }^{35}$ should be reviewed by a judiciary "institutionally free, and indeed bound, to make its own judgment unembarrassed by presumptions." 36 Also, no deference is due when the Court is confronting only "parts of Congress"-such as HUAC pillorying Barenblatt ${ }^{37}$ or the House excluding Adam Clayton Powell ${ }^{38}$-in contrast to the complete, formal legislative process consisting of passage by both houses and either presidential approval or the overriding of a veto.

II.

Because Structure and Relationship in Constitutional Law is written in Black's characteristically elegant yet elliptical style-a style which sometimes tends to camouflage his many original thoughts-a discussion of the book may profitably begin with an attempt to articulate exactly how the structural approach differs from the prevailing mode of textual interpretation.

First of all, there would seem to be nothing unusual in our constitutional system about the interpretive technique of inferring. Inference is commonly employed in a variety of constitutional contexts:

32. P. 77.

33. P. 78.

34. 357 Ư.S. 116 (1958).

35. See Korematsu v. United States, 323 U.S. 214 (1944).

36. P. 79.

37. Barenblatt v. United States, 360 U.S. 109 (1959).

38. Powell v. McCormick, 395 U.S. 486 (1969). 
to bolster express rights with prophylactic remedies, to protect express rights with supportive rights, and to supplement express rights with derivative rights. The search-and-seizure exclusionary rule, for example, is inferred from the "right of the people to be secure" which is stated explicitly in the Fourth Amendment. ${ }^{39}$ The privilege against selfincrimination, established by the specific language of the Fifth Amendment, gives rise to the inference that the prosecutor is not to comment to the jury on the defendant's failure to take the stand. ${ }^{40}$ The majority in Griswold $v$. Connecticut ${ }^{41}$ inferred from several explicit constitutional provisions which safeguard various aspects of individual privacy the existence of an omnibus right of privacy which extends beyond the contours of the explicit provisions. Black's structural and relational approach is thus distinctive not because it employs inferential reasoning, but because the departure points for that reasoning are not the familiar textual passages of grant or prohibition, but rather other textual passages that recognize political and societal structures and relationships without expressly delineating any rights and powers that flow therefrom.

At various points in the discussion Black refers to seven such "structures and relationships" (apparently employing the phrase to denote a generic concept rather than two separate phenomena): 1) the bare existence, irrespective of its character, of a federal government that is supreme over the state governments; 2) the fact that the electorate is assigned a central role in the federal government; 3 ) the existence of a federal court system as one of the agencies for redress of citizens' grievances; 4) "the economic structure of nationhood"; 42 5) the structure of "national unity," quite apart from governmental or economic needs, a structure which, for example, "warrants inference as to mobility of population";43 6) the concept of "citizenship"; 7) the status of "alien." Each of these structures and relationships is either established in some detail by the text of the Constitution or else is plainly envisioned by an important provision of that text. ${ }^{44}$ Thus,

39. See Mapp v. Ohio, 367 U.S. 643 (1961).

40. See Griffin v. California, 380 U.S. 609 (1965).

41. 381 U.S. 479 (1965).

42. Pp. 20-21.

43. P. 28.

44. See, e.g., Article VI, section 2 (federal government supremacy); Article I, section 2, Article IV, section 4, Amendment XIV, section 2, Amendments XV, XVII, XIX, XXIV (central role of the electorate); Article I, section 8, Article III (federal court system); Article I, section 8, section 10 (economic nationhood); Article IV, section 2, Article VI, section 2, Amendment XIV (national unity); Article IV, section 2, Amendment XIV (citizenship); Article I, section 8, para. 4, Article IV, section 2 (alienage). 
Black does not suggest a free-wheeling, imaginative, highly resultoriented search for the basic structures and relationships; rather, they must be "soundly enough established to furnish a basis for this kind of legal thought." 45

Where Black is prepared to be free-wheeling, imaginative, and highly result-oriented is in the process of inferring from established structures and relationships. He offers no guidelines for the eager law student who would master the methodology of structural inference. Why, for example, in Carrington v. Rash, do not the overlapping structures of federal and state government give rise to a "reasonableness" test rather than to the "no-disadvantage-to-the-performance-of-a-federalduty" rule which Black infers? Could not the structure of representative democracy, with its assumptions of open political dialogue and periodic free elections, support an inference that the Dennis communists should not be allowed to participate in a system whose rules they refuse to accept? The inferences, it would seem, can radiate from the structures and relationships in a number of ideological directions, depending on who is doing the inferring. In this regard, Black's system of inference from textual structures and relationships does not appear to differ significantly from the familiar system of inferences from the textual passages of grant and prohibition or from the system of inferences from Anglo-American traditions which Justice Frankfurter and others employed when attempting to fashion a body of rules and principles out of the formless clay of "due process." 46

In a number of other respects, moreover, Black's proposal is linked to the dominant method of textual interpretation. While his inference process begins with structures and relationships rather than grants, prohibitions, traditions and societal norms, the process ends, just as do the more familiar systems of inference, with rules, principles, presumptions, ad hoc balancing tests, and the like. In addition, Black makes it clear that he offers his system of structural and relational inferences only as a supplement to, not as a substitute for, the dominant technique of textual interpretation: "so long as we continue to look on our Constitution as a part of the law applicable in court, just so long the work of sheer textual interpretation will be a great part-probably the greatest part-of judicial work in constitutional law." 47 And in cases of inconsistency between structural implications

45. P. 23.

46. See, e.g., Frankfurter's concurring opinion in Adamson v. California, 332 U.S. 46, 59 (1947), and Kadish, Methodology and Criteria in Due Process Adjudication: $A$ Survey and Criticism, 66 YALE L.J. 319 (1957).

47. P. 31 . 
and textual commands, the text must prevail, "for the structure and relations concerned are themselves created by the text, and inference drawn from them must surely be controlled by the text." 48

Structure and Relationship in Constitutional Law deserves to be treated, therefore, as a serious proposal for reform, not as an impossible dream. In evaluating the book as a practical reform proposal, two dimensions of inquiry seem appropriate. First, would a widespread adoption of the method of structural inference make much of a difference in the results judges would reach in actual cases? Second, would structural reasoning improve the process of constitutional interpretation?

\section{III.}

Professor Black, a "judicial activist proudly self-confessed," 49 admits that his enthusiasm for the structural approach has a lot to do with the results he believes it would facilitate, results he feels are desperately needed in a society "sick with the disease of racism."50 Accepting, for the moment, the validity and even the sufficiency of such an avowedly result-oriented justification, is there any reason to believe that a widespread utilization of structural reasoning would actually lead to different judicial results? Black clearly believes that it would, and I share his belief, although for reasons different than those put forward in his discussion.

It is doubtful whether there will ever be much agreement among observers of the legal system on the critical question of whether, and to what extent, doctrinal formulations exert influence over the results judges reach. Stated in the abstract, the argument for doctrinal impact would seem to proceed as follows: If, in fact, some judges are able (and willing) to decide concrete factual disputes by reasoning as objectively as possible along established doctrinal lines, then a major shift in the predominant doctrinal idiom would unquestionably produce markedly different results. Even if, moreover, judges often decide disputes by first opting for a particular result on the basis of intuitive reactions or conscious political preferences, and then reasoning backwards to fashion a justification for the results in doctrinal terms, a shift in doctrine could still lead to different results. First,

48. $I d$.

49. P. 72 .

50. P. 53. 
there will be instances in which a judge simply cannot justify his preferred result within the existing doctrinal framework without engaging in the kind of transparent distortion that is sure to bring on professional, if not public, disapproval. Such disapproval may not deter a judge who cares only for the result, but it seems that few cases summon up that kind of strong-arm judicial commitment. For cases in which the judge's devotion to the result is less than religious, or in which his sensitivity to professional criticism is especially great, the availability of a structural justification could save a decision that would have to be abandoned under a system consisting exclusively of textual inferences. Furthermore, even in areas of constitutional controversy like race and dissent where intense judicial preferences tend to override doctrinal constraints, structural reasoning could affect the judge's initial intuitive and political preferences by altering the information that is considered relevant, the policy considerations that are put forth, and even the lawsuits that are brought, particularly by law reform groups with long-range litigation strategies.

When the discussion is directed toward specific decisions, however, it is rather difficult to demonstrate the impact that a shift toward structural reasoning might have. Black is very careful throughout the book to illustrate his general ideas with concrete examples, yet in only five of the more than twenty cases he discusses does he suggest that the structural approach might have yielded a different result rather than simply a more satisfying justification for the result that actually obtained. Four of his five examples of possible doctrinal impactGitlow v. New York, Dennis v. United States, Barenblatt v. United States, and Korematsu v. United States-seem unpersuasive. Gitlow, Dennis and Barenblatt were free speech cases in which the regulatory interest prevailed; it is inconceivable that a Court majority sympathetic to the speakers could not have found textual support in the First Amendment, or that a Court majority sympathetic to the regulatory claim would have felt compelled by a structural argument to rule in favor of the speakers. Similarly, in Korematsu, it is implausible that a majority willing to distinguish away seemingly applicable equal protection principles in order to uphold the internment of JapaneseAmerican citizens would have ruled differently had the point been stressed that it was not an action of the "whole Congress" but only that of a military commander that was under review. Black's fifth example, Collins v. Hardyman, ${ }^{51}$ resulted in the dismissal of a federal

51. 341 U.S. 651 (1951). 
prosecution against private individuals who had broken up a public meeting. The "no-state-action" rationale ${ }^{52}$ for the decision would have been avoidable under the structural approach, which could support an inference of congressional power to punish all interference with the decision-making processes of the electorate..$^{53}$ But Black himself admits that when the Court is strongly committed to a result, as it has been recently when racial discrimination has been at issue, state action "always turn[s] out to be there." Collins is explicable in terms of judicial apathy, not doctrinal impotence.

It would be a mistake, however, for result-oriented critics to dismiss the structural approach as unimportant simply because these concrete examples of possible doctrinal impact are unconvincing. In this instance, Black's normally helpful penchant for specific examples may have done his argument a disservice, for the potential impact of structural reasoning cannot be appreciated by looking solely to past, rather conventionally-framed disputes involving particular laws or discrete exercises of governmental or private power. The importance of the structural approach may lie precisely in its potential for broadening judicial perspectives. The textual approach is under some strain presently because it is striving to cope with cosmic, systemic injustices, such as legislative malfunctioning and political repression, with a set of rather modest, narrowly-conceived constitutional norms. Because the structural approach recognizes a much broader, more comprehensive set of constitutional norms, it may facilitate a judicial response to citizen complaints that concern systemic shortcomings as well as those that involve particularized grievances.

Several possibilities come to mind: the system of campaign financing, the distribution of power within legislatures, the structure of public school financing, the various processes of natural resource utilization and dissipation, the balkanized nature of governmental authority in metropolitan areas, and the system of surveillance and data collection regarding political beliefs and associations. Presently, it seems, there is a good deal of dissatisfaction, among persons of widely divergent political faiths, with many of these "systems." Yet few lawyers, judges, and legal scholars know much about how the systems really operate, and fewer still have tried to measure the performance of the systems

52. The Court narrowly construed 42 U.S.C. 1985(3) not to reach the alleged conduct because "if this complaint meets the requirements of this Act, it raises constitutional problems of the first magnitude ...."341 U.S. 651, 659.

53. See United States v. Cruikshank, 92 U.S. 542 (1876) (dictum), another example of structural reasoning in the nineteenth century.

54. P. 55 . 
against a coherent set of norms. The complex, integrated injustices of the current age do not fit easily into the pigeonholes of specific grants and prohibitions, nor do ancient Anglo-American traditions offer standards for decision.

Take, for example, the problem of political campaign financing. Most people probably find it disconcerting that the successful presidential candidate in 1968 spent much more on the campaign than did his two major opponents, or that the field of viable political candidates seems to be narrowing to those who can invest huge private fortunes in the venture or who have previously obtained heavy media exposure as a result of family associations or success in the world of entertainment (including space exploration). Is not this overall system of campaign financing, if suspicions are confirmed, a very serious undermining of the structure of representative democracy? Should not lawyers, judges, and legal scholars at least look into current fund-raising practices to see if they drain the time and energy of the candidate and force him to make ideological and personnel commitments he would not otherwise make? Should not the legal community at least explore the feasibility of effective remedies such as compulsory free media time, detailed accounting requirements, and flat expenditure ceilings keyed to the number of votes cast in the last election?

It is by no means clear that structural thinking would lead to anything more than a reasoned conclusion that judicial intervention into the complexities of campaign financing-or school financing, or internal legislative organization, or the environment-would be both unmanageable and unwarranted. That conclusion cannot be considered foreordained, however; the experience with the reapportionment cases, $^{65}$ for example, suggests that novel and complex forms of judicial intervention can sometimes succeed, even as applied to one of the basic institutions of the society and in the face of long-standing traditions and cherished political prerogatives.

The reapportionment cases also suggest, of course, that innovative, sweeping judicial intervention can germinate under the traditional textual approach. Developments such as New York Times v. Sullivan ${ }^{56}$ and the recent relaxation of traditional standing requirements ${ }^{57}$ under-

55. See, e.g., Reynolds v. Sims, 377 U.S. 533 (1964); Lucas v. Forty-Fourth General Assembly, 377 U.S. 713 (1964); Avery v. Midland County, 390 U.S. 474 (1968); Kirkpatrick v. Preisler, 894 U.S. 526 (1969).

56. 376 U.S. 255 (1964). See also Kalven, The New York Times Case: $A$ Note on "The Central Meaning of the First Amendment," 1964 Sup. Cr. REv. 191.

57. See, e.g., Flast v. Cohen, 392 U.S. 83 (1968); Association of Data Processing Service Organizations v. Camp, 397 U.S. 150 (1970). 
score the point. The systemic injustices mentioned above could also be addressed by the judiciary without resort to structural reasoning; campaign financing practices, for example, could be scrutinized under the First Amendment, the Equal Protection Clause, or some amalgam of the two. ${ }^{58}$ Nevertheless, the structural approach is potentially important because it might regularize and legitimate the sporadic, strained broadening of judicial perspectives that is already underway. An established tradition of structural reasoning might result in judicial scrutiny of systemic injustices as a matter of course rather than as a matter of spectacular and exceptional doctrinal breakthrough, and in a judiciary that would feel obliged before opting for nonintervention to articulate reasons why the Constitution can play no role in the righting of systemic wrongs.

IV.

For those of us who share Black's general outlook on political and social problems, and on the question what role the Supreme Court ought to play in attacking those problems, the structural approach seems worth a try if there is any possibility that it will lead to better judicial results-better, that is, in terms of one's own values. Others with different views, however, will not be persuaded. Recognizing this, Black quite diligently offers in support of his system a number of arguments that speak to its virtues as a decision-making process quite apart from the desirability of the results the process might spawn. And as was true, unfortunately, for the preceding inquiry concerning results, a number of these "process-type" arguments can be evaluated only in terms of one's highly intuitive and highly disputable hypothesis regarding how judges actually decide constitutional cases.

Black suggests that structural reasoning would enhance predictability, clarity, and candor in the judicial decision-making process. "Why," he asks, "should one not explicitly base [innovative] holdings, not on Humpty-Dumpty textual manipulation, but on the sort of political inference which not only underlies the textual manipulation but is, in a well constructed opinion, usually invoked to support the interpretation of the cryptic text?"'59 After describing a particular inference which he would be willing to make, he states "I think this an eminently sensible implication. You may not think so. If you do not,

58. Cf. Williams v. Rhodes, 393 U.S. 23 (1968).

59. P. 29. 
then we can and must begin to argue at once about the practicalities and proprieties of the thing, without getting out dictionaries whose entries will not really respond to the question we are putting, or scanning utterances, contemporary with the text, of persons who did not really face the question we are asking." $60 \mathrm{He}$ concludes his first lecture, introducing the idea of structural reasoning, with an affirmation of his "faith, fundamentally, that clarity about what we are doing, about the true or the truly acceptable grounds of judgment, is both a good in itself, and a means to sounder decision." 61

But what is there to indicate that structural reasoning would not likewise, and to the same extent, fall prey to "Humpty-Dumpty manipulation"? If, as suggested above, doctrinal constraints exert little influence in sensitive problem areas such as race and protest, then it seems likely that judicial decisions in those controversial areas would continue to be made on the basis of rather crude intuitions and preconceptions, only to be rationalized in terms of some high-minded set of structural rather than textual inferences, inferences unrelated in either event to the actual bases for decision. If it were thus true that the "practicalities and proprieties" that really decide cases for judges would not be the same "practicalities and proprieties" that would comprise structural discourse, the net gain in predictability, clarity, and candor would be zero.

It is conceivable, on the other hand, that if the structural style of justification were more commonly and more consciously employed, it might exert an influence over judges' thought patterns, perhaps resulting in a refinement and sophistication of intuitions and preconceptions-a development which in its own right might constitute a process-type argument in favor of the structural approach. Any refinement and sophistication, however, would depend on there being some sort of relationship between the high-minded structural abstractions that Black has in mind and the essentially mundane, if not crass, motivations for judicial decision which are of central importance under the decision-making hypothesis set out above. One such relationship that seems significant concerns the critical factor of information flow. To the extent that structural reasoning would result in a refashioning of lawsuits, with different information coming to the attention of judges, Black's structural approach may well lead to judicial intuitions and preconceptions that can be considered to be more sophisticated

60. P.p. 22-23.

61. P. 32 . 
and thereby, quite apart from the subjective desirability of the results that might ensue, improvements of "process."

One other process-type argument put forth by Black raises a host of interesting questions, not only concerning the subtleties of the judicial psyche but also regarding those "higher speculations of jurisprudence" which he wishes to avoid. "There has remained," he laments, "a suppressed uneasiness about the incorporation of the First Amendment into the Fourteenth-suppressed because it came to seem so unthinkable that there could be no federal protection of free speech against local interference, but an uneasiness because the conversion of the phrase 'due process of law' into a statement of preferred position must continue to be suspected of being arbitrary." $22 \mathrm{He}$ even suggests that the textual approach would be improved by the adoption of a supplementary structural methodology, for the Court's interpretation of the Fourteenth Amendment could proceed "with more confidence if we had the feeling that, after all, it was not mere textual accident in 1866 that made all the difference ...."'63

At one level, he appears to be saying that "suppressed uneasiness" is inherently bad for the judicial process because it causes fuzzy thinking. While some might argue, as Justice Frankfurter seemingly did, that suppressed uneasiness is a highly salutary constraint on judges not directly responsible to the electorate, Black may be attempting to distinguish between suppressed uneasiness and thoughtful self-restraint. The latter, it might be suggested, is likely to result in a rational, measured forbearance commensurate with the Court's strengths and weaknesses in terms of expertise and political capital. The former, in contrast, will more often manifest itself in the form of indecisiveness -in bold moral pronouncements followed by puny remedies, in coherent principles applied in an incoherent, erratic fashion. Particularly in an era when the Court is on the defensive politically, when shrewd, precise political calculation is called for in order to avoid both foolish forays and unnecessary retreats, it would seem to be of some importance that the judicial mind not be clouded with lingering intimations of illegitimacy.

The problem is that decisions alchemized out of inferences from structure and relationship might also be "suspected of being arbitrary" so as to induce suppressed uneasiness. That possibility brings Black precisely to the point where he does not want to be-to the questions

62. P. 95 .

63. P. 66 . 
concerning decisional legitimacy which have, in recent times, been discussed most frequently (and rather unprofitably, in my opinion) in terms of Herbert Wechsler's call for "neutral principles."

The structural approach cannot be considered an advance in Wechslerian terms: there is nothing to suggest that structural decisions would be any more "neutral," "generalized," or "principled," whatever one might mean by those amorphous terms. Black's thesis may, however, constitute a major contribution to the legitimacy debate in a quite different and quite neglected regard-that concerning the relevance of the framers' original intent. ${ }^{65}$

Black rightly believes that a court's fiat, or even its documented conclusion, as to the framers' intent should not be a sufficient reason for a constitutional decision-that other requirements such as "practical rightness" and (perhaps) adequate generality must be satisfied. But his pronounced discomfort with the disingenuousness of textual reasoning also suggests-and here one must read between the linesa belief that fidelity to some conception of the framers' intentions is a necessary component of decisional legitimacy.

It is easy to throw around generalizations about "growth" and "keeping in tune with the times" and "adaptation" and the impossibility of discerning a collective intent, but to be legitimate must not a judicial decision that purports to override an otherwise sovereign act of will bear some particular relation to the higher sovereign act of will-the collective decision to draft, pass, and ratify the relevant constitutional provision-which is the judicial decision's only ostensible source of authority? Can a constitutional decision-even a "neutral," "principled" constitutional decision-ever be legitimate if all the Court can say, honestly, is "We think this is a good rule and a proper application?" Should not the Court have to be able to say, honestly, "We think it more likely than not that the framers (defined as a sufficient majority at each step in the process) would have thought this a good rule and a proper application?" Or at least, "We think it more likely than not that the framers wanted to delegate to us, future generations of justices, the decision what rule should govern these kinds of cases?" Perhaps an adequate theory of legitimacy can be built around the

64. Toward Neutral Principles of Constitutional Law, 73 HARv. L. REv. 1 (1959).

65. The best works to date on the nature and relevance of original intent are: $A$ Bickel, The Least Dangerous Branch 98-110 (1962); C. Miller, The Supreme Court AND THE UsEs OF HIsTORY (1969); tenBroek, Use by the United States Supreme Court of Extrinsic Aids in Constitutional Construction, 26 CALIF. L. REv. 287, 437, 664 (1938) and 27 Calif, L. REv. 157, 899 (1939); Kelly, Clio and the Court: An Illicit Love Affair, 1965 SUP. Cr. REV. 119. 
idea of societal acquiescence-a judicial entitlement to power by adverse possession-or upon some notion that the framers "assumed the risk" when they used general language, but those theories have yet to be expostulated in any detail.

Judicial activists have tended to shy away from these difficult questions concerning the original intent-in part, no doubt, because of the suspicion that those questions have conservative answers. It is striking how the most careful constitutional scholars content themselves with flat assertions when it comes time to dismiss the significance of the framers' original understanding. Martin Shapiro is probably the most blunt about it: "[ $[\mathrm{E}] \mathrm{ven}$ if the historical evidence were clearer than it is, it is irrelevant." " $[I]$ t is not the founders" intentions but our intentions that count." in the work of Alexander Bickel, ${ }^{67}$ Robert Burt, ${ }^{68}$ and Leonard Levy, ${ }^{60}$ each of whom punctuates an impressive, careful inquiry into the framers' specific intent on a given issue with a conclusion that the specific intent is unimportant.

Black's structural approach may represent a beginning probe in the quest for a theory of legitimacy that can enable the Court to hand down bold, catalytic (and, hopefully, politically discreet) decisions without either having to abandon the symbolic and real advantages that come from having roots in the past, or else having to engage in a more-or-less conscious process of distortion in discussing the original understanding. The structural approach suggests, quite plausibly, that there was a meaningful original intent-a "sovereign act of will"that went into the creation of the Constitution's structures and relationships as well as into the creation of its grants and prohibitions. If the structures and relationships embody general values whose meaning and context evolve over time, then dramatic judicial intervention is appropriate in order to harmonize modern developments with the general values rooted in the original structure. This intervention can take the form of creating particular rights, powers, and affirmative duties that may act as counterweights to structural mutations, or it may even take the form of direct efforts to change the primary structures. In any event, the endeavor can be justified as an attempt to

66. Freedom of Speech: The Supreme Court and Judicial Review 93 (1966).

67. The Original Understanding and the Segregation Decision, 69 HARv. L. REv. 1 (1955).

68. Miranda and Title II: A Morganatic Marriage, 1969 Sup. CT. Rev. 81.

69. Freedom of SPEEch and Press in EARLY AMERICAN History: Legacy of SuppresSION (1963). 
restore (more accurately, to approximate in the modern setting) the political power equilibrium envisioned by the framers.

Not surprisingly, this line of reasoning raises a host of difficult questions: is there any reason to believe that inferences from structure and relationship made by twentieth-century judges will yield a power equilibrium anything like that envisioned by the framers? Is not it just as likely that the unhindered evolution of political institutions would produce that intended equilibrium, or indeed, constitute what the framers had in mind? Moreover, was there in 1787, or in 1868 , any coherent vision, or even a rough, vague consensus, on what amounts to "equilibrium" in the distribution of political power? And even if there were, why should the visions of those two generations be frozen into eternity? It is one thing to give enduring operative significance to a few particular, focused value choices that at one time commanded an extraordinary vote of approval. Similarly, there are strong reasons for giving enduring significance to a "concept of ordered liberty" which consists of general norms that have slowly, gradually achieved consensus approval over a broad span of time. It is quite another thing to ascribe such significance to a grand design or a radical visioneven if that design or vision may have commended itself to an entire age.

These questions are not necessarily unanswerable. One can imagine, for example, a constitutional theory that persuasively justifies giving disproportionate, enduring emphasis to the visions of those particular ages-such as the two great generative periods in American constitutional history, 1787 and 1868-when the polity is boldly striking forth after a cathartic experience, when interest in politics is at an apex among the general citizenry, when the most talented men in society are drawn to the affairs of state, when political thinking and discussion proceed in terms of overall systems and long-range purposes rather than increments, adjustments, and crisis responses. One can imagine, also, a partial answer to skeptics who claim that collective intent, particularly collective intent involving many different collegial bodies, is an impossible concept. While the framers may have had to bury their irreconcilable disagreements in general language, at some point there must have been a consensus on the minimal content of a particular clause or structure. Whatever else freedom of the press, for example, was intended to mean, there was a clear collective intent that comprehensive, discretionary licensing of the press by government was to be prohibited.

While the feared conservative conclusions might eventually result 
from a more elaborate exploration of the concept of original intent, Black's book is highly suggestive to the opposite effect. Hopefully, Structure and Relationship in Constitutional Law will stimulate other judicial activists to do battle on this turf, for there is no reason yet apparent why the original-intent segment of the legitimacy debate must be forfeited to the advocates of judicial restraint or textual absolutism. In any event, if Black succeeds in encouraging judges, lawyers, and scholars to think more clearly about the nature and relevance of original intent, he will, by that alone, have contributed to a significant improvement of the process of constitutional adjudication.

\section{V.}

Black concludes by placing his discussion of the structural approach in perspective: "As I think back over what I have said in these lectures, I realize that the most I can hope for is that I may have suggested some lines along which some of you may later find it fruitful to think. One who reads at all in constitutional law will know, ruefully, that there is no new thing to be said, and that when you think you have said something new you later find that others have said much the same thing before." 70

Whether or not somebody has said much the same thing before, we can be grateful that Charles Black is saying it now, because now is when we need to hear it. No doubt this music will sound discordant to a profession that has long celebrated the virtues of "thinking small." But unless the legal profession accepts Professor Black's invitation to start "thinking big," there is a danger that the judiciary will be unequipped to play even its customary catalytic role in the nation's coming political experience. That prospect should be deeply troubling (and energizing) to those who do not wish to see such issues as prison conditions, civil commitment practices, media access, plastic and neon ugliness, overpopulation, data collection, political party structures, and biological behavior control (and thought control) left to the unprodded and unchecked statesmanship and foresight of legislators.

70. P. 93. 